Article

\title{
Biological Activities and Chemical Composition of Santolina africana Jord. et Fourr. Aerial Part Essential Oil from Algeria: Occurrence of Polyacetylene Derivatives
}

\author{
Charaf Eddine Watheq Malti ${ }^{1}$, Clémentine Baccati ${ }^{2}$, Magali Mariani ${ }^{2}$, Faiçal Hassani ${ }^{3}$, \\ Brahim Babali ${ }^{3}$, Fewzia Atik-Bekkara ${ }^{1}$, Mathieu Paoli ${ }^{2}$, Jacques Maury ${ }^{2}$, Félix Tomi ${ }^{2, *}$ (]) \\ and Chahrazed Bekhechi ${ }^{1}$ \\ 1 Laboratoire des Produits Naturels, Département de Biologie, Université Abou Bekr Belkaïd, \\ Imama Tlemcen 13000, Algeria; mcew.malti@gmail.com (C.E.W.M.); f_atik@yahoo.fr (F.A.-B.); \\ bekhechichahrazed@yahoo.fr (C.B.) \\ 2 Université de Corse-CNRS, UMR 6134 SPE, Route des Sanguinaires, 20000 Ajaccio, France; \\ clementine.baccati@gmail.com (C.B.); mariani_m@univ-corse.fr (M.M.); \\ mathieu.paoli@univ-corse.fr (M.P.); maury_j@univ-corse.fr (J.M.) \\ 3 Laboratoire d'Ecologie et Gestion des Ecosystèmes Naturels, Département d'Ecologie et Environnement, \\ Université Abou Bekr Belkaïd, Imama Tlemcen 13000, Algeria; faicalhassani@yahoo.fr (F.H.); \\ miharb_babali@hotmail.fr (B.B) \\ * Correspondence: felix.tomi@univ-corse.fr; Tel.: +33-495-52-4122
}

Academic Editor: Francesca Mancianti

Received: 24 November 2018; Accepted: 29 December 2018; Published: 8 January 2019

\begin{abstract}
The chemical composition of 18 oil samples of Santolina africana isolated from aerial parts at full flowering, collected in three locations in eastern Algeria was determined by GC(RI), GC/MS and ${ }^{13} \mathrm{C}$-NMR analysis. The major components were: germacrene D, myrcene, spathulenol, $\alpha$-bisabolol, $\beta$-pinene, 1,8-cineole, cis-chrysanthenol, capillene, santolina alcohol, camphor, terpinen-4-ol and lyratol. The chemical composition appeared homogeneous and characterized by the occurrence of four derivatives which exhibited a conjugated alkene dialkyne moiety. They were identified for the first time in an essential oil from S. africana. The collective oil sample exhibited moderate antimicrobial and antioxidant activities whereas the anti-inflammatory activity presented a real potential. $\mathrm{IC}_{50}$ value of Santolina africana essential oil $(0.065 \pm 0.004 \mathrm{mg} / \mathrm{mL})$ is 5-fold higher than $\mathrm{IC}_{50}$ value of NDGA used as positive control.
\end{abstract}

Keywords: Santolina africana Jord. et Fourr.; Asteraceae; essential oil composition; ${ }^{13} \mathrm{C}-\mathrm{NMR}$; antimicrobial activity; antioxidant activity; anti-inflammatory activity

\section{Introduction}

The Santolina genus belongs to the Asteraceae family and is represented by more than 10 species widely distributed in Mediterranean area [1]. In all Santolina species, Santolina viridis W. (South of France and North of Spain), S. pectinata Lag. (= S. rosmarinifolia L.) (Iberian Peninsula) and S. chamaecyparissus L. are the most widely spread species around the world. S. africana Jord. et Fourr. is synonym of Ormenis africana (Jord. et Fourr.) Litard. et Maire and S. chamaecyparissus L. var. africana B. et T. It is an endemic species to the North Africa (Morocco, Algeria and Tunisia) $[2,3]$ that grows naturally in forests and steppe pastures. This species is a bushy, green or ashy sub-shrub. The stems are woody, with floriferous branches erect in tuft, bare and thickened at the apex. The lower leaves are linear-cylindrical with short and obtuse segments. The bracts are ovate-oblong. The outer corollas are tube-styled ovary. The flowerheads are discoidal, yellow, homogamous [2]. 
Some members of Santolina genus have been known as medicinal plants for a long time. S. africana is used in Moroccan folk medicine as a stomachic, abortive, anthelmintic, antidiabetic and emmenagogue [4,5]. In Tunisia, it is traditionally used for its hypoglycemic effect and for the treatment of stomache pains [6]. Some biological activities have been reported for the extracts or essential oils of $S$. africana, such as antioxidant activity [6-8], antimicrobial activity [7], accaricidal activity [9] and antidiabetic activity [8].

The chemical composition of the essential oils of species belonging to the genus Santolina has been widely studied [10]. S. chamaecyparissus is probably the most investigated species of this genus [11-22]. The composition of other species such as S. corsica [23,24], S. insularis [25,26], S. rosmarinifolia [27-29] was also reported. Monoterpenes such as 1,8-cineole, camphor, artemisia ketone and myrcene were the major components of essential oils isolated from some Santolina species growing in different regions of the word.

Conversely, only five studies have reported on the chemical composition of S. africana oil. The chemical composition of the volatile compounds isolated from various parts of the plant have been substantially investigated. Fdil et al. [4] compared the chemical composition of three oil samples isolated from different organs (stems, leaves and flowers) of S. africana plants harvested in Marrakech province (Morocco). The three samples oils exhibited respectively a composition dominated by oxygenated monoterpenes: camphor $(69.14 \% / 71.36 \% / 80.44 \%)$, borneol $(20.33 \% / 18.13 \% / 12.34 \%)$ and bornyl acetate $(7.08 \% / 8.12 \% / 3.50 \%)$. The stem oil contained also noticeable amounts of $\alpha$-humulene $(3.14 \%)$ while the flowers oil exhibited an appreciable content of 1,8-cineole (3.32\%). Another aerial part oil sample of Moroccan origin exhibited a similar composition, with camphor (54.3\%), borneol (17.24\%), bornyl acetate (8.61\%) and 1,8-cineole (5.27\%) as main components [5]. A Tunisian oil sample (stems and leaves) was characterized by a high content of terpinen-4-ol (54.96\%), followed by $\alpha$-terpineol $(14.06 \%)$ and borneol (8.37\%) [9]. Concerning Algerian S. africana, only two studies are reported in the literature. An oil sample (flowers) harvested in Constantine province (Algeria) was dominated by acenaphtane (25.23\%), calarene (21.54\%) and ocimene (17.44\%) [7]. A drastically different composition has been reported for an aerial parts oil sample collected in the same region, $\beta$-eudesmol (14.58\%) and $\beta$-pinene (12.78\%) being the major compounds, followed by 1,8 -cineole $(10.02 \%)$, curcumene $(7.96 \%)$, myrcene (6.94\%) and spathulenol (5.96\%) [18].

It appears from literature data that the essential oil (EO) from aerial parts of $S$. africana exhibits a tremendous chemical variability. Moreover, most of the papers reported on the analyses of only one or two oil samples and obviously, the reported compositions are not always representative of $S$. africana. Thus, the aim of the present work is to characterize the EO produced by this plant growing wild in Batna province (Algeria). Eighteen oil samples isolated from aerial parts at full flowering stage harvested in three locations have been analyzed by GC, GC/MS and ${ }^{13} \mathrm{C}-\mathrm{NMR}$. Then, the biological activities of the EO have been investigated as antimicrobial, antioxidant and anti-inflammatory activities, this latter has never been investigated in any previous papers.

\section{Results}

Aerial parts of wild S. africana were collected in May in three locations (Figure 1) (six samples per location). Yields of EO isolated by hydrodistillation, calculated $w / w$ vs. dry material varied drastically from sample to sample ranging from 0.03 to $0.17 \%$ even within a location (Table S1). As it could be seen from Table S1, the highest yields were obtained from Hamla (0.08-0.14\%, samples H1-6) and Bouilef (0.15\%, sample B5 and 0.17\%, sample B6) and the lower from Bouilef and Fesdis $(0.03 \%$ for samples B2, B4 and F6). 


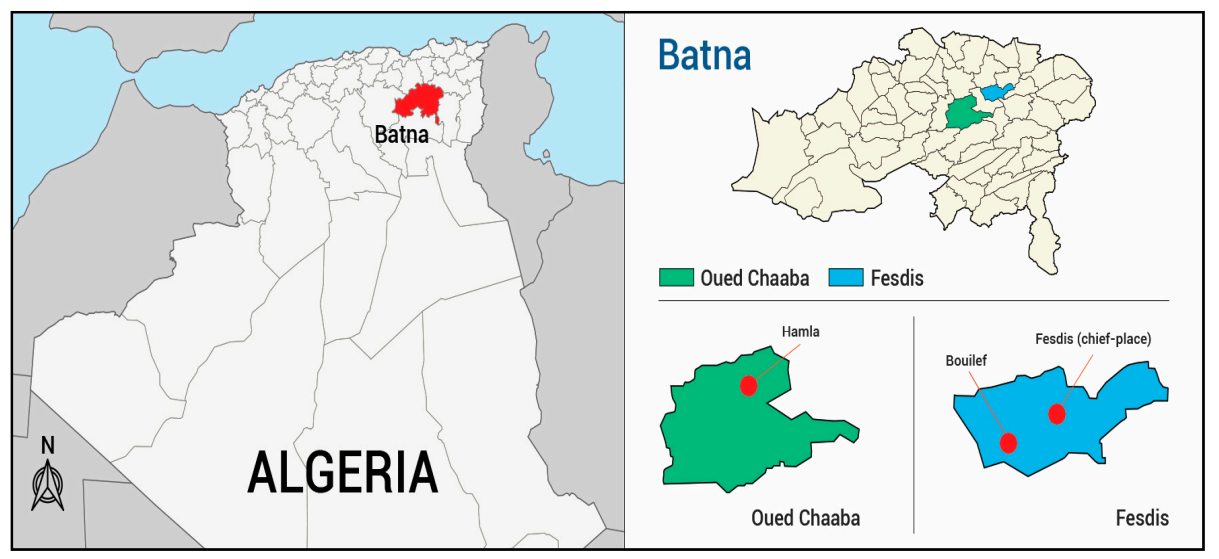

Figure 1. Sampling locations of Santolina africana from eastern of Algeria.

\subsection{Chemical Composition of Essential Oil}

Aerial parts oils samples were submitted to GC-FID analysis, to determine the retention indices (RIs) of the EO components on two columns of different polarity and to GC/MS analysis. Further analysis by ${ }^{13} \mathrm{C}-\mathrm{NMR}$ confirmed the identification of the main components. To allow the identification of four polyacetylene derivatives present at moderate or low levels, a composite sample (F1 to F6) was submitted to column chromatography (CC) over silica gel. Nine fractions were obtained and analyzed by GC-FID, GC/MS and ${ }^{13} \mathrm{C}-\mathrm{NMR}$. In total, 91 components accounting for $92.4 \%$ and $96.1 \%$ of the whole oil chemical composition were identified (Table S1, Figure 2), including forty-three monoterpenes, thirty-one sesquiterpenes, five phenylpropanoids, six polyacetylene derivatives and six others. The composition of S. africana EOs is generally homogeneous; the oils were found to possess little differences in the chemical composition but considerable variation in the levels of the individual components. All the samples were characterized by high proportions of monoterpenes (51.5-69.7\%), except three samples: B4, B5 and F6 which were dominated by sesquiterpenes (44.3-55.9\%). The main components were germacrene $\mathrm{D}(0.1-25.3 \%)$, myrcene $(4.2-20.9 \%)$, spathulenol (2.5-20.7\%), $\alpha$-bisabolol (2.2-20.0\%), $\beta$-pinene (2.4-18.7\%), 1,8-cineole (5.0-16.8\%), cis-chrysanthenol (0.7-16.5\%), capillene $(0.1-16.9 \%)$, santolina alcohol $(0.2-14.0 \%)$, camphor (0.2-7.9\%), terpinen-4-ol (1.8-7.3\%) and lyratol (0.1-6.7\%). Other two oxygenated monoterpenes: lyratal (tr-2.7\%) and chrysanthenone (tr-4.5\%), three sesquiterpene hydrocarbons: $\alpha$-curcumene $(0.3-3.2 \%), \gamma$-curcumene $(0.1-2.6 \%)$ and bicyclogermacrene $(0.1-6.3 \%)$ as well as two oxygenated sesquiterpenes: $\beta$-elemol (up to $3.5 \%$ ) and $\beta$-eudesmol (tr-3.0\%) were present in appreciable amounts. Then, one sample for each location (B1, F5 and H1) and five other samples which exhibited various compositions (B3, B4, B5, B6 and H6) were presented in Table S1.

For instance, the content of capillene (a polyacetylene derivative) reached $16.9 \%$ in sample $\mathrm{H} 6$ vs. (0.2-7.5\%) for the other samples of Hamla and vs. (tr-0.4\%) for the samples of Fesdis and Bouilef. The samples B3 and B4 were characterized a high amount of oxygenated sesquiterpenes: spathulenol (15.1\% and $20.7 \%$, respectively) associated with $\alpha$-bisabolol (13.2\% and $20.0 \%$, respectively). In the last two atypical samples (B5 and B6), a sesquiterpene hydrocarbon (germacrene D) was present as main compound (25.3 and $20.2 \%$. respectively) vs. $(0.0-7.5 \%)$ for all other samples. 

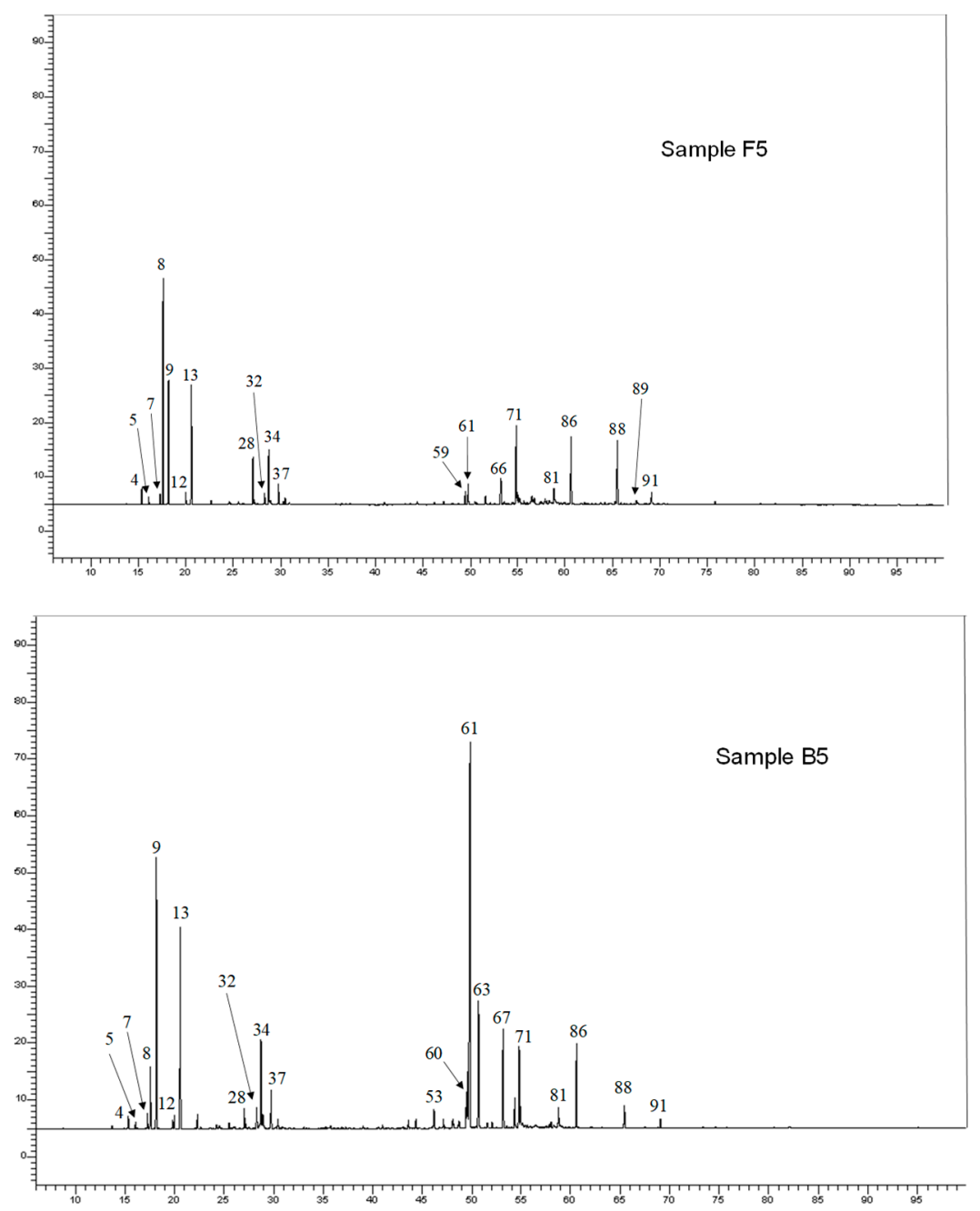

Figure 2. Gas chromatograms of Santolina africana EO (samples F5 up and B5 down). The numbered peaks are the identified components (see Table S1).

\subsection{Identification of Polyacetylene Derivatives}

In this study, the identification of four compounds proposed by the MS library was achieved. These compounds were presumed to be two pairs of stereoisomers $(\mathrm{m} / z=200$ and $\mathrm{m} / z=198)$ corresponding to spiroacetalenol derivatives. Indeed, polyacetylene compounds are commonly found in the Asteraceae family [30]. The identification of these compounds was achieved by ${ }^{13} \mathrm{C}-\mathrm{NMR}$ spectroscopy after fractionation (fractions $\mathrm{Fr} 4$ and Fr6, see Experimental part) by comparison of their spectral data with those reported in the literature. (E)- and (Z)-tonghaosu $(m / z=200)$ were identified by comparison with data previously described by Chanotiya et al. [31]. (E)-2-(2', 4'-Hexadiynylidene)-1,6-dioxaspiro[4.4]-nona-3,7-diene was identified according to literature data [32] (Figure S1). In the ${ }^{13} \mathrm{C}$-NMR spectrum of $\mathrm{Fr} 4$ in which the $E / Z$ ratio was close to $8 / 1$ $(46.6 \% / 6.3 \%)$, a series of 13 peaks corresponding to the $Z$ isomer was observed. It is the first time that the four spiroacetalenol derivatives [30] were identified in an EO from S. africana. The contents of (E)-2-(2',4'-hexadiynylidene)-1,6-dioxaspiro[4.4]-nona-3,7-diene and (E)-tonghaosu reached 7.3\% (B3) and $3.8 \%$ (B6), respectively. These compounds were previously reported in EO from Chrysanthemum coronarium L. (aerial parts) [33] and in some solvent extracts from C. leucanthemum (roots) [34], C. coronarium (aerial parts) [35] and S. chamaecyparissus (leaves and buds) [36]. 


\subsection{Chemical Variability}

The 18 samples were submitted to statistical analyses: the principal components analysis (PCA, covariance) (Figure 3, Table S1), in which the plan defined by the two axes F1 and F2 described $51.05 \%$ of the total variance of the population (the two axes F1 and F2 accounted for $31.70 \%$ and $19.35 \%$. respectively). It may be noted that the composition of all samples was qualitatively quite similar. Although the compositions of the individual samples varied substantially for various components, it was not possible to distinguish groups within the essential oil samples. Therefore, one main group (16 samples) and differentiated two atypical compositions (B5 and B6, Figure 3) were observed. Indeed, B5 and B6 were discriminated by a high percentage of sesquiterpene hydrocarbons (bicyclogermacrene, (E)- $\alpha$-bisabolene, $\gamma$-curcumene) and particularly germacrene D, $25.3 \%$ (B5) and $20.2 \%$ (B6) vs. $0-7.5 \%$ for the other samples. All the samples from the Fesdis location were homogeneous, while the composition of the samples from the Hamla location appeared much less homogeneous. Conversely, it appeared that the Bouilef samples, located between the two others locations (Fesdis and Hamla) were different, so two samples (B3 and B4) were aggregated to those of the Fesdis location, whereas the two samples B1 and B2 were quite similar to the Hamla samples (Figure 3).

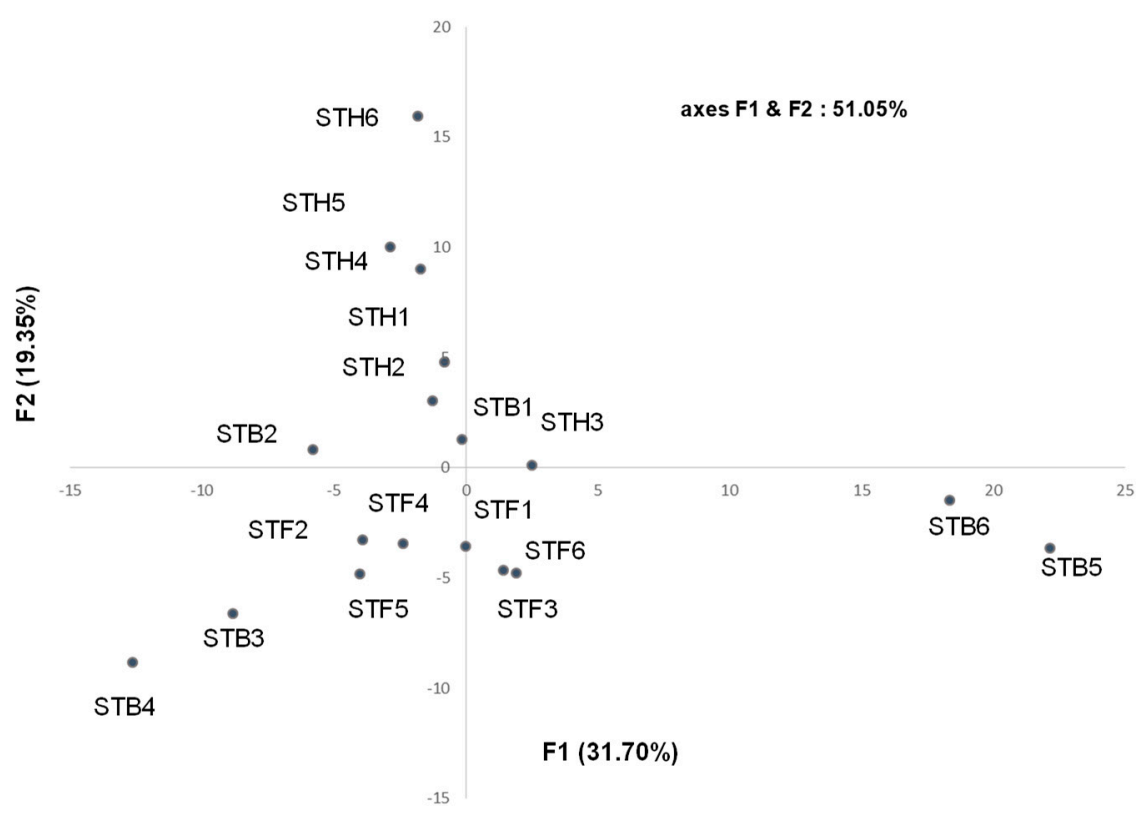

Figure 3. PCA of Santolina africana essential oil samples.

\subsection{Antimicrobial Activity}

The antimicrobial activity of the EO of S. africana isolated from the aerial part at full flowering was assayed against four bacteria, two yeasts and three filamentous fungi, using the agar disc diffusion method (Table 1). 
Table 1. Antimicrobial activity of S. africana essential oil.

\begin{tabular}{|c|c|c|c|c|c|c|c|c|}
\hline \multirow{2}{*}{ Microorganisms } & \multirow{2}{*}{$\begin{array}{c}\text { Essential Oil } \\
(15 \mu \mathrm{L} / \text { disc })\end{array}$} & \multicolumn{6}{|c|}{ Positive Controls } & \multirow{2}{*}{$\begin{array}{c}\begin{array}{c}\text { Negative Contro } \\
\text { (DMSO) }\end{array} \\
6.0\end{array}$} \\
\hline & & CHL & VAN & GMN & CIP & FLU & NY & \\
\hline Escherichia coli & $8.00 \pm 0.0$ & $25.0 \pm 0.0$ & $6.0 \pm 0.0$ & $23.0 \pm 0.0$ & $35.5 \pm 0.7$ & - & - & 6.0 \\
\hline Klebsiella pneumoniae & $6.0 \pm 0.0$ & $21.3 \pm 0.6$ & $6.0 \pm 0.0$ & $20.0 \pm 0.0$ & $30.5 \pm 0.7$ & - & - & 6.0 \\
\hline Staphylococcus aureus & $19.7 \pm 0.6$ & $25.5 \pm 0.7$ & $17.0 \pm 0.0$ & $21.0 \pm 0.0$ & $32.0 \pm 0.0$ & - & - & 6.0 \\
\hline Bacillus cereus & $6.0 \pm 0.0$ & $29.5 \pm 0.7$ & $6.0 \pm 0.0$ & $21.0 \pm 0.0$ & $37.0 \pm 0.0$ & - & - & 6.0 \\
\hline $\begin{array}{c}\text { Candida albicans } \\
\text { ATCC } 10231\end{array}$ & $13.0 \pm 0.0$ & - & - & - & - & $6.0 \pm 0.0$ & $16.0 \pm 0.0$ & 6.0 \\
\hline $\begin{array}{c}\text { Candida albicans } \\
\text { ATCC } 26790\end{array}$ & $15.3 \pm 1.5$ & - & - & - & - & $15.0 \pm 0.0$ & $19.0 \pm 1.0$ & 6.0 \\
\hline \multirow{2}{*}{ Aspergillus flavus } & $20.5 \pm 0.7^{a}$ & - & - & - & - & $6.0 \pm 0.0$ & $22.3 \pm 0.6$ & 6.0 \\
\hline & $13.5 \pm 0.7^{b}$ & - & - & - & - & $6.0 \pm 0.0$ & - & 6.0 \\
\hline \multirow{2}{*}{ Aspergillus fumigatus } & $43.0 \pm 2.8^{a}$ & - & - & - & - & $6.0 \pm 0.0$ & $33.7 \pm 1.2$ & 6.0 \\
\hline & $17.5 \pm 3.5^{b}$ & - & - & - & - & $6.0 \pm 0.0$ & - & 6.0 \\
\hline \multirow{2}{*}{ Fusarium oxysporum } & $38.5 \pm 2.1^{\mathrm{a}}$ & - & - & - & - & $6.0 \pm 0.0$ & $16.0 \pm 1.0$ & 6.0 \\
\hline & $15.0 \pm 0.0^{b}$ & - & - & - & - & $6.0 \pm 0.0$ & - & 6.0 \\
\hline
\end{tabular}

CHL: Chloramphenicol, VAN: Vancomycin, GMN: Gentamicin, CIP: Ciprofloxacin, FLU: Fluconazole. NY: Nystatin were used as positive controls. Mean values of the growth inhibition zones. in $\mathrm{mm}$. including the disc diameter of $6 \mathrm{~mm}$. —: Not tested. ${ }^{a}$ : After 3 days. ${ }^{\text {b: }}$ After 5 days. 
The oil was considered active when the diameter of inhibition zone was equal to or greater than $13 \mathrm{~mm}$ [24]. The agar diffusion method showed that the oil was effective against Staphylococcus aureus, the two yeasts and the three filamentous fungi with diameters of inhibition zone ranging from $13.0 \mathrm{~mm}$ to $19.7 \mathrm{~mm}$. The most potent activity was demonstrated against Staphylococcus aureus and Aspergillus fumigatus with inhibition zones of $19.7 \mathrm{~mm}$ and $17.5 \mathrm{~mm}$ respectively. In contrast, the growth of Bacillus cereus, Klebsiella pneumoniae and Escherichia coli were not inhibited by the EO. This assumption is in accordance with previous studies on the Santolina genus. Indeed, the S. africana EO which contained acenaphtane $(25.23 \%)$, calarene $(21.54 \%)$, ocimene $(17.44 \%)$ as its major components, exhibited a moderate or low activity against the same microorganisms with diameters of inhibition zone ranging from $6.50 \mathrm{~mm}$ to $20.15 \mathrm{~mm}$. Bacillus subtilis and Staphylococcus aureus were the most susceptible to this EO, with inhibition zones of 20.15 and $19.5 \mathrm{~mm}$, respectively [7].

\subsection{Antioxidant Activity}

The results of the $\mathrm{DPPH}^{\bullet}$ free radical scavenging test were presented in Table 2 and Figure S2. The EO of the aerial parts of S. africana have a high antioxidant activity at concentrations of 32,64 , 128 and $256 \mathrm{mg} / \mathrm{mL}$, with inhibition percentages ranged between $85.54 \pm 2.17 \%$ and $100 \pm 0.00 \%$ and an $\mathrm{IC}_{50}$ value of $1.51 \pm 0.04 \mathrm{mg} / \mathrm{mL}$. However, the antioxidant potential of $S$. africana EO was found to be low than that of ascorbic acid (positive control), with a percentage inhibition of $100 \%$, at a concentration of $2 \mathrm{mg} / \mathrm{mL}$ and a significantly lower $\mathrm{IC}_{50}$ value of $0.02 \pm 0.0005 \mathrm{mg} / \mathrm{mL}$.

Table 2. $\mathrm{IC}_{50}$ values and anti-inflammatory activity of Santolina africana essential oil.

\begin{tabular}{|c|c|c|c|c|}
\hline \multirow[t]{3}{*}{ Activity } & \multicolumn{2}{|c|}{ Antioxidant } & \multicolumn{2}{|c|}{ Anti-Inflammatory } \\
\hline & Essential oil & $1.51 \pm 0.04$ & Essential oil & $0.065 \pm 0.004$ \\
\hline & Ascorbic acid & $0.02 \pm 0.0005$ & *NDGA & $0.013 \pm 0.003$ \\
\hline \multicolumn{5}{|c|}{ Anti-inflammatory activity (percentage inhibition of LOX) } \\
\hline Concentration \# & Inhibition (\%) & Concentration \# & Inhibition $(\%)$ & \\
\hline 0.015 & $23.4 \pm 4.1$ & 0.050 & $37.5 \pm 2.8$ & \\
\hline 0.025 & $28.5 \pm 5.5$ & 0.075 & $57.6 \pm 3.5$ & \\
\hline
\end{tabular}

Values are means of triplicates \pm standard deviation; ${ }^{*}$ NDGA: Nordihydroguaiaretic Acid; ${ }^{\#} \mathrm{mg} / \mathrm{mL}$.

\subsection{Anti-Inflammatory Activity}

The anti-inflammatory potential of S. africana EO was evaluated by determining its ability to inhibit lipoxygenases (LOX). Indeed, LOXs are a non-heme iron-containing dioxygenases that convert linoleic, arachidonic and other polyunsaturated fatty acid into biologically active metabolites involved in the inflammatory and immune responses. Several inflammatory processes such as arthritis, bronchial asthma and cancer are associated with an important production of leukotrienes catalysed by LOX pathway from arachidonic acid [37-40]. The inhibition of the LOX pathway with inhibitors of LOX would prevent the production of leukotrienes and therefore could constitute a therapeutic target for treating of human inflammation-related diseases. Thus, the search for new LOX inhibitors appears us critical because many of which exhibit significant anti-inflammatory activity.

The ability of S. africana EO to inhibit soybean lipoxygenase was determined as an indication of potential anti-inflammatory activity. S. africana EO exhibited an inhibition of LOX activity (Table 2). The percentage of inhibition increases with the concentration of $S$. africana $\mathrm{EO}$, i.e., $23.4 \%$ at $0.015 \mathrm{mg} / \mathrm{mL}$ to $57.6 \%$ at $0.075 \mathrm{mg} / \mathrm{mL}$ of EO. No LOX activity could be detected in the presence of $0.1 \mathrm{mg} / \mathrm{mL}$ of $S$. africana EO, suggesting almost complete inhibition of LOX activity. The $\mathrm{IC}_{50}$ values (concentration at which $50 \%$ of the lipoxygenase was inhibited) were determined for the S. africana EO and for the non-competitive inhibitor of lipoxygenase, the nordihydroguaiaretic acid (NDGA) (Table 2), usually used as reference in anti-inflammatory assays [38-40]. Data showed that the $\mathrm{IC}_{50}$ 
value of $S$. africana essential oil $(0.065 \pm 0.004 \mathrm{mg} / \mathrm{mL})$ is 5 -fold higher than $\mathrm{IC}_{50}$ value of NDGA $(0.013 \pm 0.003 \mathrm{mg} / \mathrm{mL})$.

\section{Discussion}

The composition of S. africana aerial part oils isolated from plants growing wild in eastern Algeria (Batna) was different from those reported for oils from Morocco [4,5], Tunisia [9] and Algeria (Constantine) [7,18], but it should be pointed that a similar composition has been reported for flowerhead oil of $S$. chamaecyparissus from Tunisia, which also contained 1,8-cineole, $\beta$-eudesmol $(10.49 \%)$, terpinen-4-ol (6.97\%), spathulenol (5.80\%), camphor $(5.27 \%)$ and germacrene $\mathrm{D}(5.03 \%)$ as major components [20]. Other compounds also occurred as main constituents: $\delta$-cadinene $(6.55 \%)$ and myrtenol $(4.26 \%)$ which are present at low amounts in all our samples (tr-0.4\%).

We can assume that the moderate or low antimicrobial activity of S. africana EO is related to one or various major components: 1,8-cineole $(12.8 \%)$, germacrene D $(7.2 \%)$, spathulenol $(6.2 \%)$, cis-chrysanthenol (6.0\%), myrcene (5.8\%), $\beta$-pinene (5.2\%), $\alpha$-bisabolol $(5.2 \%)$, terpinen-4-ol $(3.2 \%)$, santolina alcohol $(3.1 \%)$, lyratol $(2.4 \%)$, capillene $(2.2 \%),(E)$ - $\alpha$-bisabolene $(2.0 \%)$, limonene $(1.9 \%)$, camphor (1.6\%) and $\beta$-elemol (1.4\%). 1,8-Cineole was previously described as antibacterial against S. aureus [41] while myrcene which accounted for $57.2 \%$ in the fraction Fr1 [23] was already reported as ineffective against $S$. aureus [23,42]. It has been reported also that $\beta$-pinene, $\alpha$-pinene and germacrene $\mathrm{D}$ had slight activity against a panel of microorganisms. Indeed, the essential oil of Pinus nigra ssp. pallasiana ( $\alpha$-pinene. $42.3 \%$; germacrene D. $30.6 \%$ ) exhibited a low antimicrobial activity against the same strains with MICs in the range $10-20 \mathrm{mg} / \mathrm{mL}$ [43], so it has been demonstrated in the literature that the inhibitory activity of an EO results from a complex interaction between its different constituents, which may produce additive, synergistic or antagonistic effects, even for those present at low concentrations, i.e., 1,8-cineole in combination with camphor has shown higher antimicrobial effects [44]. In parallel, Lemos et al. [45] reported that the essential oil of Rosmarinus officinalis which contained camphor (24.4-35.9\%) as major compound exhibited a high antimicrobial activity against S. aureus with MICs in the range $0.5-2.0 \mu \mathrm{L} / \mathrm{mL}$. Otherwise, an interesting antimicrobial activity of a lyratol-rich fraction $(84 \%)$ was observed against $S$. aureus $(19 \mathrm{~mm})$, suggesting that lyratol could be the main responsive of the antimicrobial properties of Santolina corsica [23]. It has been summarized also that oxygenated terpenes, as well as alcohols which are present in appreciable amounts in our oil, are active but with differing specificity and levels of activity [46,47].

In previous studies, Derouiche et al. [7] reported a percentage inhibition of the free radical DPPH of the S. africana flower EO of about $13.80 \%$ at a concentration of $0.1 \mathrm{M}$, a value much lower than ascorbic acid (more than $70 \%$ of inhibition) used as a positive control. Nouasri et al. [17] evaluated the antioxidant activity of the essential oil of the aerial parts of $S$. chamaecyparissus using two methods, the $\mathrm{DPPH}^{\bullet}$ free radical scavenging test and the $\beta$-carotene bleaching test. They reported that $S$. chamaecyparissus $\mathrm{EO}$ had low antioxidant capacity to reduce $\mathrm{DPPH} \mathrm{H}^{\bullet}$ radical with an $\mathrm{IC}_{50}$ of about $43.01 \pm 8.04 \mathrm{mg} / \mathrm{mL}$, compared to BHT $\left(\mathrm{IC}_{50}=0.072 \pm 0.001 \mathrm{mg} / \mathrm{mL}\right.$ ) and ascorbic acid $\left(\mathrm{IC}_{50}=0.004 \pm 0.001 \mathrm{mg} / \mathrm{mL}\right)$. The $\beta$-carotene bleaching test revealed that the $\mathrm{EO}$ had a moderate activity with a percentage inhibition of the oxidation of linoleic acid of the order of $47.00 \pm 3.13 \%$, a value that is higher than that of ascorbic acid tested (11.05\%), but much lower than BHT $(96.92 \%)$.

The measurement of antioxidant activity has revealed that aerial parts of $S$. africana EO exhibited an antioxidant activity that could have an eventual possibility to be used in the food industry, as a natural antioxidant agent, for the preservation of foodstuffs, or in the field of health, for the prevention of various diseases.

Concerning the anti-inflammatory activity, the low ratio between the two values of $\mathrm{IC}_{50}$ (S. africana EO vs. NDGA) makes it possible to consider the S. africana $\mathrm{EO}$ as a high inhibitor of the LOX activity [48]. Thus, according to the results, S. africana EO exhibits a high inhibition of LOX activity, suggesting an anti-inflammatory potential. 


\section{Materials and Methods}

\subsection{Plant Material}

Aerial parts of Santolina africana were collected during the flowering period in May 2016 in three locations in the Batna province (Eastern Algeria): Fesdis (Fesdis: F1-6; Bouilef: B1-6) and Oued Chaaba (Hamla: H1-6) (Figure 1). Identification of the plant material was performed by Dr. Babali B., (Laboratory of Ecology and Management of Natural Ecosystems, University of Tlemcen, Imama Tlemcen, Algeria). A voucher specimen has been deposited at the Laboratory of Natural Products (Department of Biology, University of Tlemcen, Algeria), under the accession $n^{\circ}$ A. 2844 . The essential oil was obtained by hydrodistillation of dried aerial parts (around 150-280 g) for $2 \mathrm{~h}$. Yields have been calculated from dry material.

\subsection{Gas Chromatography (GC) Analysis}

GC analyses were performed on a Clarus 500 FID gas chromatograph (PerkinElmer, Courtaboeuf, France) equipped two fused silica gel capillary columns $(50 \mathrm{~m} \times 0.22 \mathrm{~mm}$, film thickness $0.25 \mu \mathrm{m})$, BP-1 (polydimethylsiloxane) and BP-20 (polyethylene glycol). The oven temperature was programmed from 60 to $220{ }^{\circ} \mathrm{C}$ at $2{ }^{\circ} \mathrm{C} / \mathrm{min}$ and then held isothermal at $220^{\circ} \mathrm{C}$ for $20 \mathrm{~min}$, injector temperature: $250{ }^{\circ} \mathrm{C}$; detector temperature: $250{ }^{\circ} \mathrm{C}$; carrier gas: hydrogen $(1.0 \mathrm{~mL} / \mathrm{min})$; split: $1 / 60$. The relative proportions of the oil constituents were expressed as percentages obtained by peak area normalization, without using correcting factors. Retention indices (RIs) were determined relative to the retention times of a series of $n$-alkanes with linear interpolation ('Target Compounds' software of PerkinElmer).

\subsection{Mass Spectrometry}

The EOs were analyzed with a PerkinElmer TurboMass detector (quadrupole, PerkinElmer, Courtaboeuf, France), directly coupled to a PerkinElmer Autosystem XL (PerkinElmer), equipped with a fused silica gel capillary column $(50 \mathrm{~m} \times 0.22 \mathrm{~mm}$ i.d., film thickness $0.25 \mu \mathrm{m}), \mathrm{BP}-1$ (dimethylpolysiloxane). Carrier gas, helium at $0.8 \mathrm{~mL} / \mathrm{min}$; split: $1 / 75$; injection volume: $0.5 \mu \mathrm{L}$; injector temperature: $250{ }^{\circ} \mathrm{C}$; oven temperature programmed from 60 to $220^{\circ} \mathrm{C}$ at $2{ }^{\circ} \mathrm{C} / \mathrm{min}$ and then held isothermal (20 min); ion source temperature: $250^{\circ} \mathrm{C}$; energy ionization: $70 \mathrm{eV}$; electron ionization mass spectra were acquired over the mass range 40-400 Da.

\subsection{NMR Analysis}

${ }^{13}$ C-NMR analyses were performed on an AVANCE 400 Fourier Transform spectrometer (Bruker, Wissembourg, France) operating at $100.623 \mathrm{MHz}$ for ${ }^{13} \mathrm{C}$, equipped with a $5 \mathrm{~mm}$ probe, in $\mathrm{CDCl}_{3}$, with all shifts referred to internal tetramethylsilane (TMS). ${ }^{13} \mathrm{C}-\mathrm{NMR}$ spectra were recorded with the following parameters: pulse width (PW): $4 \mu$ s (flip angle $45^{\circ}$ ); acquisition time: $2.73 \mathrm{~s}$ for $128 \mathrm{~K}$ data table with a spectral width (SW) of $220.000 \mathrm{~Hz}$ (220 ppm); CPD mode decoupling; digital resolution $0.183 \mathrm{~Hz} / \mathrm{pt}$. The number of accumulated scans ranged 2000-3000 for each sample (around $40 \mathrm{mg}$ of oil in $0.5 \mathrm{~mL}$ of $\left.\mathrm{CDCl}_{3}\right)$. Exponential line broadening multiplication $(1.0 \mathrm{~Hz})$ of the free induction decay was applied before Fourier transformation.

\subsection{Identification of Individual Components}

Identification of the components was based: (i) on comparison of their GC retention indices (RIs) on polar and apolar columns, determined relative to the retention times of a series of $n$-alkanes with linear interpolation ('Target Compounds' software of PerkinElmer), with those of authentic compounds and (ii) on comparison of the signals in the ${ }^{13} \mathrm{C}-\mathrm{NMR}$ spectra of EOs with those of reference spectra compiled in the laboratory spectral library, with the help of a laboratory-made software [49-51]. In the investigated samples, individual components were identified by NMR at contents as low as $0.4 \%$. Several compounds were identified by 
comparison of ${ }^{13} \mathrm{C}-\mathrm{NMR}$ chemical shifts with those reported in the literature, for instance capillene and capillin [27,52]; (E)-2-(2',4'-hexadiynylidene)-1,6-dioxaspiro[4.4]-nona-3,7-diene [32]; $(Z)$ and (E)-tonghaosu. (2-(2', $4^{\prime}$-hexa-diynyl-idene)-1,6-dioxaspiro[4.4]-non-3-ene [31,53].

\subsection{Essential Oil Fractionation}

A composite oil sample (F1 to F6, Fesdis; $247.9 \mathrm{mg}$ ) was submitted to flash chromatography (silica gel: $35-70 \mu \mathrm{m}$ ). Nine fractions (Fr1-Fr9) were eluted with a mixture of solvents of increasing polarity (pentane:diethyl ether, 100:0 to 0:100, and pure methanol); Fr1 (10.3 mg) and Fr2 (12.6 mg); pentane: $\mathrm{Et}_{2} \mathrm{O}, 98: 2$; $\mathrm{Fr} 3$ (9.2 mg); pentane: $\mathrm{Et}_{2} \mathrm{O}$, 95:5 Fr4 (14.4 mg); pentane: $\mathrm{Et}_{2} \mathrm{O}, 90: 10 \mathrm{Fr} 5$ (18.8 mg); pentane: $\mathrm{Et}_{2} \mathrm{O}$, 75:25 Fr6 (86.5 mg); pentane: $\mathrm{Et}_{2} \mathrm{O}$, 50:50 Fr7 (18.7 mg); pentane: $\mathrm{Et}_{2} \mathrm{O}, 0: 100 ; \mathrm{Fr} 8$ (22.3 mg) and pure methanol, $\mathrm{Fr} 9(15.6 \mathrm{mg})$. All fractions of chromatography were analyzed by GC (RI), GC/MS and ${ }^{13} \mathrm{C}-\mathrm{NMR}$.

\subsection{Antimicrobial Activity of the Essential Oil}

\subsubsection{Microbial Strains}

Antimicrobial activity of the aerial part EO (Collective sample Bouilef-Hamla) were evaluated against two Gram-positive bacteria (Staphylococcus aureus ATCC 6538 and Bacillus cereus ATCC 25921) and two Gram-negative bacteria (Escherichia coli ATCC 8739, Klebsiella pneumoniae ATCC 700603), two yeasts (Candida albicans ATCC 26790 and C. albicans ATCC 10231) and three filamentous fungi (Fusarium oxysporum MNHN 963917, Aspergillus fumigatus MNHN 566 and Aspergillus flavus MNHN 994294).

\subsubsection{Screening of Antimicrobial Activity}

The agar diffusion method [54] was used for the determination of antimicrobial activity of the EOs. Briefly, a suspension of the tested microorganisms $\left(1 \mathrm{~mL}\right.$ of a suspension at $10^{6}$ cells $/ \mathrm{mL}$ for bacteria and yeasts, $10^{7}$ cells $/ \mathrm{mL}$ for S. aureus and $10^{4}$ spores $/ \mathrm{mL}$ for filamentous fungi) was spread on the solid media plates, using Mueller-Hinton agar for bacteria, Sabouraud dextrose for yeasts and PDA for filamentous fungi. Filter paper discs ( $6 \mathrm{~mm}$ in diameter) were impregnated with $15 \mu \mathrm{L}$ of the oil and $5 \mu \mathrm{L}$ of DMSO and placed on the surface of inoculated plates. The activity was determined by measuring the inhibitory zone diameter in $\mathrm{mm}$ after incubation for $24 \mathrm{~h}$ at $37^{\circ} \mathrm{C}$ for bacteria, $24-48 \mathrm{~h}$ at $30{ }^{\circ} \mathrm{C}$ for yeasts and 3 to 5 days at $25^{\circ} \mathrm{C}$ for filamentous fungi. Fluconazole (FLU $25 \mu \mathrm{g} / \mathrm{disc}$ ), nystatin (NY $30 \mu \mathrm{g} / \mathrm{disc}$ ) were used as reference antifungal against yeasts and filamentous fungi and chloramphenicol (CHL $30 \mu \mathrm{g} /$ disc), ciprofloxacin (CIP $10 \mu \mathrm{g} /$ disc), gentamicin (GMN $10 \mu \mathrm{g} / \mathrm{disc}$ ), vancomycin (VAN $30 \mu \mathrm{g} /$ disc) were used as positive controls against bacteria. DMSO was used as negative control. Each test was performed in duplicate or in triplicate.

\subsection{DPPH Radical Scavenging Activity}

The antioxidant activity was measured on a sample of EO (Collective sample Fesdis F1-6). The antioxidant activity of $S$. africana $\mathrm{EO}$ was measured on the basis to scavenge of the 2.2-diphenyl-1-picrylhydrazil (DPPH ${ }^{\bullet}$ ) free radical, according to the experimental protocol of Blois [55]. A volume of $2.5 \mathrm{~mL}$ with various concentrations $(256,128,64,32,16,8,4,2,1,0.5,0.25,0.125,0.0625$, 0.03125 and $0.015625 \mathrm{mg} / \mathrm{mL}$ ) of the EO in absolute ethanol were added to $1 \mathrm{~mL}$ of an ethanolic solution of DPPH at $0.03 \mathrm{mg} / \mathrm{mL}$. For each concentration, a blank was prepared. In parallel, a negative control is prepared by mixing $2.5 \mathrm{~mL}$ of absolute ethanol with $1 \mathrm{~mL}$ of ethanolic solution of DPPH. After incubation in the dark for $30 \mathrm{~min}$ at room temperature, the absorbance was measured against a blank at $517 \mathrm{~nm}$. The activity of the EO was compared to ascorbic acid as a positive control. DPPH free radical scavenging activity in percentage (\%) was calculated using the following formula:

$$
\mathrm{DPPH} \text { scavenging activity }(\%)=\left[\left(\mathrm{A}_{\text {control }}-\mathrm{A}_{\text {sample }}\right) / \mathrm{A}_{\text {control }}\right] \times 100
$$


with: $A_{\text {control }}$ is the absorbance of the negative control; $A_{\text {sample }}$ is the absorbance of the tested sample.

The concentration of the $\mathrm{EO}$ required for the $50 \%$ reduction in the initial concentration of $\mathrm{DPPH}\left(\mathrm{IC}_{50}\right)$ was calculated from the graph plotted of percentage inhibition against essential oil concentrations.

\subsection{Anti-Inflammatory Capacity of Santolina africana Essential Oil}

The anti-inflammatory capacity of $S$. africana essential oil (collective sample Fesdis F1-6) was evaluated by in vitro lipoxygenase inhibition assay [56-58]. The in vitro analysis for lipoxygenase inhibitory activity was performed using Lipoxidase type I-B (Lipoxygenase, LOX, EC 1.13.11.12) from Glycine max (soybean) purchased from Sigma-Aldrich Chimie (Saint-Quentin-Fallavier, France). It was determined by kinetic mode of spectrophotometric determination method, which was performed by recording the rate of change in absorbance at $234 \mathrm{~nm}$. Indeed, the increase of absorbance at $234 \mathrm{~nm}$ due to formation of 13-hydroperoxides of linoleic acid (substrate used for LOX inhibition activity assay) [56-58].

A stock solution of LOX was prepared by dissolving around 5.7 units/mL of LOX in $0.2 \mathrm{M}$ borate buffer pH 9.0 ( 1 unit corresponding to $1 \mu \mathrm{mol}$ of hydroperoxide formed per min). Five concentrations of S. africana EO in dimethylsulfoxide (DMSO) were tested as inhibitor solution for LOX inhibition activity assay: $1.5,2.5,5.0,7.5$ and $10.0 \mathrm{mg} / \mathrm{mL}$.

The LOX inhibition assays were performed by mixing $10 \mu \mathrm{L}$ of LOX solution with $10 \mu \mathrm{L}$ of inhibitor solution in $970 \mu \mathrm{L}$ of boric acid buffer $(0.2 \mathrm{M} ; \mathrm{pH} 9.0)$ and incubating them briefly at room temperature. The reaction started by addition of $10 \mu \mathrm{L}$ of substrate solution (Linoleic acid, $25 \mathrm{mM}$ ) and the velocity was recorded for $30 \mathrm{~s}$ at $234 \mathrm{~nm}$. One assay was measured in absence of inhibitor solution and one assay was measured with DMSO mixed with distilled water (99.85\% of DMSO in distilled water) which made it possible to eliminate the inhibition effect of DMSO. No inhibitor effect of DMSO on the LOX activity was detected and the LOX activity measured without inhibitor solution was considered as control (100\% enzymatic reaction). All assays were performed on triplicate. The percentage of lipoxygenase inhibition was calculated according to the equation:

$$
\text { Inhibition } \%=\left(\mathrm{V}_{0 \text { control }}-\mathrm{V}_{0 \text { sample }}\right) \times 100 / \mathrm{V}_{0 \text { control }}
$$

$\mathrm{V}_{\text {Ocontrol }}$ is the activity of LOX in absence of inhibitor solution and $\mathrm{V}_{\text {Osample }}$ is the activity of LOX in presence of inhibitor solution [58]. The $\mathrm{IC}_{50}$ was calculated by the concentration of S. africana EO in DMSO inhibiting $50 \%$ of LOX activity.

\subsection{Data Analysis}

Principal components analysis (PCA) was performed using Xlstat (Adinsoft, Paris, France) [59].

Supplementary Materials: The following are available online, Table S1: Chemical composition of 18 samples of Santolina africana aerial part essential oil, Figure S1: Structure of polyacetylenes derivatives 88, 89, 90 and 91 , Figure S2: Antioxidant test of Santolina africana essential oil and ascorbic acid against DPPH ${ }^{\bullet}$

Author Contributions: F.A.-B. and C.B. (Chahrazed Bekhechi) conceived and designed the experiments. C.E.W.M. performed sampling, extractions, antimicrobial and antioxidant activities. C.B. (Clementine Baccati) and C.B. (Chahrazed Bekhechi) performed GC, GC/MS, NMR experiments. F.H. and B.B. performed identification and description of the plant. M.M. and J.M. performed anti-inflammatory activity. M.P. performed statistical analyses. C.B. (Chahrazed Bekhechi), J.M. and F.T. contributed to the preparation of the manuscript.

Funding: This research received no external funding.

Acknowledgments: C.B. (Chahrazed Bekhechi) thanks the University of Corsica for a financial support (Associated Professor, September 2018).

Conflicts of Interest: The authors declare no conflict of interest. 


\section{References}

1. Derbesy, M.; Touche, J.; Zola, A. The essential oil of Santolina chamaecyparissus L. J. Essent. Oil Res. 1989, 1, 269-275. [CrossRef]

2. Quézel, P.; Santa, S. Nouvelle flore de l'Algérie et des régions désertiques méridionales; Éditions du Centre National de la Recherche Scientifique: Paris, France, 1963; pp. 972-977.

3. Dobignard, A.; Chatelain, C. Index synonymique de la flore d'Afrique du nord Dicotyledoneae: Acanthaceae-Asteraceae; Conservatoire et Jardin botaniques de la ville de Genève: Genève, Belgique, 2011; p. 363.

4. Fdil, R.; Lmachraa, I.; Fdil, N.; Ezoubeiri, A.; Gadhi, C.A. Huile essentielle des parties aériennes de Santolina africana. Bull. Soc. Pharm. Bordeaux 2011, 150, 47-60.

5. Lmachraa, I.; Fdil, R.; Fdil, N.; Mouzdahir, A. Huile essentielle de Santolina africana (Jord. \& Fourr.) du Maroc: Composition chimique et isolement des deux principaux constituants. J. Mater. Environ. Sci. 2014, 5, 67-72.

6. Ben Mansour, R.; Gargouri, B.; Bouaziz, M.; Elloumi, N.; Belhadj Jilani, I.; Ghrabi, Z.; Lassoued, S. Antioxidant activity of ethanolic extract of inflorescence of Ormenis africana in vitro and in cell cultures. Lipids Health Dis. 2011, 10, 78-84. [CrossRef] [PubMed]

7. Derouiche, K.; Zellagui, A.; Gherraf, N.; Bousetla, A.; Dehimat, L.; Rhouati, S. Chemical composition, antimicrobial and antioxidant activities of the essential oils of Santolina africana flowers, endemic in Algeria. J. Biosci. Biotechnol. 2013, 2, 201-206.

8. Béjaoui, A.; Boulila, A.; Ben Salem, I.; Boussaid, M. Chemical composition and bioactivities of the polyphenolic-rich extract of Ormenis africana Jord. and Fourr. Int. J. Food Prop. 2017, 20, 1786-1795. [CrossRef]

9. Attia, S.; Grissa, K.L.; Mailleux, A.C.; Heuskin, S.; Lognay, G.; Hance, T. Acaricidal activities of Santolina africana and Hertia cheirifolia essential oils against the two-spotted spidermite (Tetranychus urticae). Pest Manag. Sci. 2012, 68, 1069-1076. [CrossRef]

10. Tundis, R.; Loizzo, M.R. A Review of the traditional use, phytochemistry and biological activities of the genus Santolina. Planta Med. 2018, 84, 627-637. [CrossRef]

11. Demirci, B.; Ozek, T.; Baser, K.H.C. Chemical composition of Santolina chamaecyparissus L. essential oil. J. Essent. Oil Res. 2000, 12, 625-627. [CrossRef]

12. Garg, S.N.; Gupta, D.; Mehta, V.K.; Kumar, S. Volatile constituents of the essential oil of Santolina chamaecyparissus Linn. from the Southern hills of India. J. Essent. Oil Res. 2001, 13, 234-235. [CrossRef]

13. Tognolini, M.; Barocelli, E.; Ballabeni, V.; Bruni, R.; Bianchi, A.; Chiavarini, M.; Impicciatore, M. Comparative screening of plant essential oils: Phenylpropanoid moiety as basic core for antiplatelet activity. Life Sci. 2006, 78, 1419-1432. [CrossRef] [PubMed]

14. Grosso, C.; Figueiredo, A.C.; Burillo, J.; Mainar, A.M.; Urieta, J.S.; Barroso, J.G.; Coelho, J.A.; Palavra, A.M. Supercritical fluid extraction of the volatile oil from Santolina chamaecyparissus. J. Sep. Sci. 2009, 32, 3215-3222. [CrossRef] [PubMed]

15. Djeddi, S.; Djebile, K.; Hadjbourega, G.; Achour, Z.; Argyropoulou, C.; Skaltsa, H. In vitro antimicrobial properties and chemical composition of Santolina chamaecyparissus essential oil from Algeria. Nat. Prod. Commun. 2012, 7, 937-940. [PubMed]

16. Ruiz-Navajas, Y.; Viuda-Martos, M.; Perez-Alvarez, J.A.; Sendra, E.; Fernández-López, J. Chemical characterization and antibacterial activity of two aromatic herbs (Santolina chamaecyparissus and Sideritis angustifolia) widely used in the folk medicine. J. Food Saf. 2012, 32, 426-434. [CrossRef]

17. Nouasri, A.; Dob, T.; Krimats, S.; Dahmane, D.; Toumi, M.; Lynda, L.; Chelgoume, C.; Racheme, F. Chemical composition, antioxidant and antimicrobial activities of the essential oil of Santolina chamaecyparissus L. of Algeria. J. Coast. Life Med. 2015, 3, 220-227.

18. Zaiter, L.; Benayache, F.; Beghidja, N.; Figueredo, G.; Chalard, P.; Chalchat, J.C.; Marchioni, E.; Benayache, S. Essential oils of Santolina africana Jord. \& Fourr. and Santolina chamaecyparissus L. J. Essent. Oil Bear. Plant. 2015, 18, 1338-1342. 
19. Khubeiz, M.J.; Mansour, G. In vitro antifungal, antimicrobial properties and chemical composition of Santolina chamaecyparissus essential oil in Syria. Int. J. Toxicol. Pharm. Res. 2016, 8, 372-378.

20. Salah-Fatnassi, K.B.H.; Hassayoun, F.; Cheraif, I.; Khan, S.; Jannet, H.B.; Hammami, M.; Aouni, M.; Harzallah-Skhiri, F. Chemical composition, antibacterial and antifungal activities of flowerhead and root essential oils of Santolina chamaecyparissus L. growing wild in Tunisia. Saudi J. Biol. Sci. 2017, 24, 875-882. [CrossRef]

21. Labed, F.; Masullo, M.; Cerulli, A.; Benayache, F.; Benayache, S.; Piacente, S. Chemical constituents of the aerial parts of Santolina chamaecyparissus and evaluation of their antioxidant activity. Nat. Prod. Commun. 2017, 12, 1605-1608.

22. Boudoukha, C.; Bouriche, H.; Elmastas, M.; Aksit, H.; Kayir, O.; Genc, N.; Senator, A. Antioxidant activity of polyphenolic leaf extract from Santolina chamaecyparissus L. (Asteraceae) and the isolated luteolin-7-O-glucoside. J. Pharm. Res. Int. 2018, 22, 1-12. [CrossRef]

23. Liu, K.; Rossi, P.G.; Ferrari, B.; Berti, L.; Casanova, J.; Tomi, F. Composition, irregular terpenoids, chemical variability and antibacterial activity of the essential oil from Santolina corsica Jordan et Fourr. Phytochemistry 2007, 68, 1698-1705. [CrossRef] [PubMed]

24. Rossi, P.G.; Panighi, J.; Luciani, A.; de Rocca Serra, D.; Maury, J.; Gonny, M.; Muselli, A.; Bolla, J.M.; Berti, L. Antibacterial action of essential oils from Corsica. J. Essent. Oil Res. 2007, 19, 176-182. [CrossRef]

25. Cherchi, G.; Deidda, D.; De Gioannis, B.; Marongiu, B.; Pompei, R.; Porcedda, S. Extraction of Santolina insularis essential oil by supercritical carbon dioxide: Influence of some process parameters and biological activity. Flavour Frag. J. 2001, 16, 35-43. [CrossRef]

26. Gnavi, G.; Bertea, C.M.; Usai, M.; Maffei, M.E. Comparative characterization of Santolina insularis chemotypes by essential oil composition. 5S-rRNA-NTS sequencing and EcoRV RFLP-PCR. Phytochemistry 2010, 71, 930-936. [CrossRef] [PubMed]

27. Palá-Paúl, J.; Pérez-Alonso, M.J.; Velasco-Negueruela, A.; Palá-Paúl, R.; Sanz, J.; Conejero, F. Seasonal variation in chemical constituents of Santolina rosmarinifolia L. subsp. rosmarinifolia. Biochem. Syst. Ecol. 2001, 29, 663-672. [CrossRef]

28. Ioannou, E.; Poiata, A.; Hancianu, M.; Tzakou, O. Chemical composition and in vitro antimicrobial activity of the essential oils of flower heads and leaves of Santolina rosmarinifolia L. from Romania. Nat. Prod. Res. 2007, 21, 18-23. [CrossRef] [PubMed]

29. Chibani, S.; Labed, A.; Kabouche, A.; Semra, Z.; Smati, F.; Aburjai, T.; Kabouche, Z. Antibacterial activity and chemical composition of essential oil of Santolina rosmarinifolia L. (Asteraceae) from Algeria. Pharm. Lett. 2013, 5, 238-241.

30. Konovalov, D.A. Polyacetylene compounds of plants of the Asteraceae family (Review). Pharm. Chem. J. 2014, 48, 615-633. [CrossRef]

31. Chanotiya, C.S.; Sammal, S.S.; Mathela, C.S. Composition of a new chemotype of Tanacetum nubigenum. Indian J. Chem. 2005, 44, 1922-1926. [CrossRef]

32. Sanz, J.F.; Falcó, E.; Marco, J.A. New Acetylenes from Chrysanthemum coronarium L. Eur. J. Org. Chem. 1990, 3, 303-305.

33. Basta, A.; Pavlović, M.; Couladis, M.; Tzakou, O. Essential oil composition of the flowerheads of Chrysanthemum coronarium L. from Greece. Flavour Frag. J. 2007, 22, 197-200. [CrossRef]

34. Wrang, P.A.; Lam, J. Polyacteylenes from Chrysanthemum leucanthemum. Phytochemistry 1975, 14, 1027-1035. [CrossRef]

35. Bohlmann, F.; Arndt, C.; Bornowski, H.; Kleine, K.M.; Herbst, P. Polyacetylenverbindungen, LVI, neue acetylenverbindungen aus Chrysanthemum-Arten. Chem. Ber. 1964, 97, 1179-1192. [CrossRef]

36. Lam, J.; Bildsøe, H.; Christensen, L.P.; Thomasen, T. Chemical constituents of Santolina chamaecyparissus. Acta Chem. Scand. 1989, 43, 799-802. [CrossRef]

37. Carrasco, A.; Ortiz-Ruiz, V.; Martinez-Gutierrez, R.; Tomas, V.; Tudela, J. Lavandula stoechas essential oil from Spain: Aromatic profile determined by gas chromatography-mass spectrometry, antioxidant and lipoxygenase inhibitory bioactivities. Ind. Crops Prod. 2015, 73, 16-27. [CrossRef] 
38. Cutillas, A.-B.; Carrasco, A.; Martinez-Gutierrez, R.; Tomas, V.; Tudela, J. Thyme essential oils from Spain: Aromatic profile ascertained by GC-MS and their antioxidant, anti-lipoxygenase and antimicrobial activities. J. Food. Drug Anal. 2018, 26, 529-544. [CrossRef]

39. Whitman, S.; Gezginci, M.; Timmermann, B.N.; Holman, T.R. Structure-activity relationship studies of nordihydroguaiaretic acid inhibitors toward soybean, 12-human, and 15-human lipoxygenase. J. Med. Chem. 2002, 45, 2659-2661. [CrossRef]

40. Jazet Dongmo, P.M.; Kuate, J.; Ngouana, V.; Damesse, F.; Tchinda Sonwa, E.; Amvam Zollo, P.H.; Menut, C. Comparaison des propriétés anti-radicalaires et anti-inflammatoires des huiles essentielles de Citrus reticulata var. madagascar et Citrus sinensis var. casagrande du Cameroun. Fruits 2008, 63, 201-208.

41. Santoyo, S.; Cavero, S.; Jaime, L.; Ibaňez, E.; Seňoráns, F.J.; Reglero, G. Chemical composition and antimicrobial activity of Rosmarinus officinalis L. essential oil obtained via supercritical fluid extraction. J. Food Prot. 2005, 64, 790-795. [CrossRef]

42. Wannissorn, B.; Jarikasem, S.; Siriwangchai, T.; Thubthimthed, S. Antibacterial properties of essential oils from Thai medicinal plants. Fitoterapia 2005, 76, 233-236. [CrossRef]

43. Šarac, Z.; Matejić, J.S.; Stojanović-Radić, Z.Z.; Veselinović, J.B.; Džamić, A.M.; Bojović, S.; Marin, P.D. Biological activity of Pinus nigra terpenes-evaluation of FtsZ inhibition by selected compounds as contribution to their antimicrobial activity. Comput. Biol. Med. 2014, 54, 72-78. [CrossRef] [PubMed]

44. Viljoen, A.; van Vuuren, S.; Ernst, E.; Klepser, M.; Demirci, B.; Başer, H.; van Wyk, B.E. Osmitopsis asteriscoides (Asteraceae)-the antimicrobial activity and essential oil composition of a Cape-Dutch remedy. J. Ethnopharmacol. 2003, 88, 137-143. [CrossRef]

45. Lemos, M.F.; Lemos, M.F.; Pacheco, H.P.; Endringer, D.C.; Scherer, R. Seasonality modifies rosemary's composition and biological activity. Ind. Crops Prod. 2015, 70, 41-47. [CrossRef]

46. Panizzi, L.; Flamini, G.; Cioni, P.L.; Morelli, I. Composition and antimicrobial properties of essential oils of four Mediterranean Lamiaceae. J. Ethnopharmacol. 1993, 39, 167-170. [CrossRef]

47. Adam, K.; Sivropoulou, A.; Kokkini, S.; Lanaras, T.; Arsenakis, M. Antifungal activities of Origanum vulgare subsp. hirtum, Mentha spicata, Lavandula angustifolia and Salvia fruticosa essential oils against humanpathogenic fungi. J. Agric. Food Chem. 1998, 46, 1739-1745.

48. Kamatou, G.P.P.; Viljoen, A.M.; Gono-Bwalya, A.B.; van Zyl, R.L.; van Vuuren, S.F.; Lourens, A.C.U.; Başer, K.H.C.; Demirci, B.; Lindsey, K.L.; van Staden, J.; et al. The in vitro pharmacological activities and a chemical investigation of three South African Salvia species. J. Ethnopharmacol. 2005, 102, 382-390. [CrossRef] [PubMed]

49. Tomi, F.; Bradesi, P.; Bighelli, A.; Casanova, J. Computer-aided identification of individual components of essential oils using carbon-13 NMR spectroscopy. J. Magn. Reson. Anal. 1995, 1, 25-34.

50. Tomi, F.; Casanova, J. ${ }^{13} \mathrm{C}-\mathrm{NMR}$ as a tool for identification of individual components of essential oils from Labiatae-A review. Acta Hortic. 2006, 723, 185-192. [CrossRef]

51. Bighelli, A.; Casanova, J. Analytical Tools for Analyzing Cymbopogon Oils. In Essential Oil Bearing Grasses-Cymbopogons, 1st ed.; Taylor and Francis: Boca Raton, FL, USA, 2009; p. 195.

52. Palá-Paúl, J.; Pérez-Alonso, M.J.; Velasco-Negueruela, A.; Ramos-Vázquez, P.; Gómez-Contreras, F.; Sanz, J. Essential oil of Santolina rosmarinifolia L. ssp. rosmarinifolia: First isolation of capillene, a diacetylene derivative. Flavour Frag. J. 1999, 14, 131-134.

53. Buono-Core, E.; Nuñez, M.V.; Lucera, A.; Vargas, R.M.; Jullian, C. Structural elucidation of bioactive principles in floral extracts of German Chamomille (Matricaria recutita L.). J. Chil. Chem. Soc. 2011, 56, 549-553. [CrossRef]

54. Performance Standards for Antimicrobial Disk Susceptibility Test; National Committee for Clinical Laboratory Standards: Wayne, PA, USA, 1997.

55. Blois, M. Antioxidant determination by the use of a stade free radical. Nature 1958, 181, 1199-1200. [CrossRef]

56. Eshwarappa, R.S.B.; Ramachandra, Y.L.; Subaramaihha, S.R.; Subbaiah, S.G.P.; Austin, R.S.; Dhananjaya, B.L. Anti-Lipoxygenase activity of leaf gall extracts of Terminalia chebula (Gaertn.) Retz. (Combretaceae). Pharmacogn. Res. 2016, 8, 78-82. [CrossRef] [PubMed] 
57. Srivastava, P.; Vyas, V.K.; Variya, B.; Patel, P.; Qureshi, G.; Ghate, M. Synthesis, anti-inflammatory, analgesic, 5-lipoxygenase (5-LOX) inhibition activities, and molecular docking study of 7-substituted coumarin derivatives. Bioorg. Chem. 2016, 67, 130-138. [CrossRef]

58. Bayala, B.; Bassole, I.H.; Gnoula, C.; Nebie, R.; Yonli, A.; Morel, L.; Figueredo, G.; Nikiema, J.-B.; Lobaccaro, J.-M.; Simpore, J. Chemical composition, antioxidant, anti-Inflammatory and anti-proliferative activities of essential oils of plants from Burkina Faso. PLoS ONE 2014, 9, 92122. [CrossRef] [PubMed]

59. Legendre, P.; Legendre, L. Numerical Ecology, 2nd ed.; Elsevier Science: Amsterdam, Netherlands, 1998.

Sample Availability: Samples of essential oils were available from the author (F.T.).

(C) 2019 by the authors. Licensee MDPI, Basel, Switzerland. This article is an open access article distributed under the terms and conditions of the Creative Commons Attribution (CC BY) license (http:/ / creativecommons.org/licenses/by/4.0/). 